\title{
Understanding How Leadership Matters: Collective Efficacy and Student Achievement
}

\author{
By Matthew E. Haug ${ }^{*} \&$ Teresa Wasonga ${ }^{\dagger}$
}

\begin{abstract}
The purpose of this study was to examine the relationships among collective efficacy factors, as measured by the Illinois 5Essentials Survey, and college readiness scores, as reported by American College Testing (ACT), for high schools in the state of Illinois. The 5Essentials have been considered crucial to school success and therefore used to describe learning environments and as basis for decisions on school improvement. However, little research has investigated the efficacy of the 5Essentials in their impact on academic achievement. This study used Illinois 5Essentials Survey and ACT data to interrogate the value of 5Essentials. Analysis of data determined that while correlational relationships do exist among the 5Essentials (collective efficacy factors) and that some have predictive qualities for student achievement, the strengths of those relationships are, at best, weak. Outcomes of this survey provide insights that policy makers should consider when recommending the use of these factors to influence school culture and student achievement.
\end{abstract}

Keywords: collective efficacy, Illinois 5Essentials Survey, reciprocal causality, self-efficacy, student achievement, leadership

\section{Introduction}

The American public education system has long been trusted to improve the lives of individuals and to help them, among other things, rise to political, economic and social success (Bennett, 1988). While this goal has remained the same over time (Kober, 2007; Willis, 1977), the structuring of the education system has changed in response to the needs of citizenry. For example, "[i]n the 21st century, at least some postsecondary education will be necessary for economic success -even survival- in an economy where the exchange of information dominates the world of work" (ACT, 2004). High school education only is no longer good enough to attain successful quality of life. In response, government leaders have called "... for a national commitment for every American to attain at least one year of postsecondary education" (Wolniak \& Engberg, 2010). In an attempt to fulfil this commitment, the state of Illinois adopted the 5Essentials as a way to organize schools for improvement (Bryke, Sebring, Allensworth, Luppescu, \& Easton, 2010).

High school education is required to transition to college. But, high schools do not operate in a vacuum, especially when the measure of student achievement is brought to bear. Like other institutions, high schools are social organizations built upon a sense of collective efficacy, which Bandura defined as “... an organizational

${ }^{*}$ School Administrator, Central CUSD \#301, USA.

†Professor, Northern Illinois University, USA. 
property and group-level attribute that represents teachers' collective beliefs about their collective power to execute a course of action that will result in a positive impact on students..." (in Evans, 2009, p. 65). When community actions result in gains for the organization, this experience feeds into future experiences and strengthens the organization as a collective. This collective is also known as organizational intentionality, whereby organizational members' work as a collective builds a sense of efficacy for the organization (Ingersoll, Sirinides, \& Dougherty, 2018; Goddard, Hoy, \& Woolfolk-Hoy, 2000). To this end, Bandura (1993) has argued that the most critical component affecting student achievement in a school is the collective efficacy, especially that of its teachers.

The perception that the collective has a positive impact on student achievement is strengthened through academic press, or "...quest for academic excellence..." (Hoy, Sweetland, \& Smith, 2002). Over time, academic press becomes a normative process with faculty believing that their efforts to bring about quality education will result in improved student performance. Ideally, this sense of reciprocal causality creates a cycle in which high levels of academic press result in high levels of student performance, which cycles back to reinforce the importance of high levels of academic press (Hoy et al., 2002). To the extent that the cycle continues, and positive impacts are observed, these cycles of success and positive impacts will influence decisions, efforts, and persistence levels among teachers and administrators (Evans, 2009). The challenge for many schools is how to identify practices for the collective that promote academic press, how to quantify these practices, how to determine the effectiveness of normative processes, and their impacts on student achievement.

Schools, especially high schools are complex public organizations that are subject to account for the use of resources and their outcomes. Because of their significant role in molding the youth of the nation, high schools continue to be targets for increased accountability and organizational effectiveness. Indeed, the No Child Left Behind Act of 2001 (NCLB) was created specifically to “...close the achievement gap with accountability, flexibility, and choice, so that no child is left behind" (NCLB, 2015). With this mandate, the federal government required that schools put in place programs that would ensure that all children, regardless of race, ethnicity, disability, socio-economic status or geographical location, would have equal opportunities for success in their school. However, complicating these efforts for school leaders are what Evans (2009) described as "social ideologies about race, class, and educational achievement...[that]...propagate the notion that white students will generally outperform African American and Hispanic students, and that wealthier students will outperform poor students on achievement and performance indicators" (p. 65). These beliefs likely influence a wide range of policies that, in turn affect schools and their communities and shape the nature of school reform efforts to meet accountability mandates. Educators as a collective function within these ideological notions. However, if educators perceive that they can execute purposeful reform plans to help all students achieve college readiness, their collective actions are likely to produce results and act as the driving force for collective efficacy in the school. 
In responding to public demands for school accountability and reforms, the state requires schools in Illinois to publish report cards which, in addition to providing student achievement data, must also "...provide feedback from, at a minimum, students in grades 6 through 12 and teachers on the instructional environment within a school..." (105 ILCS 5/2-3.153). One of the choices that schools may use to assess instructional environment is the Illinois 5Essentials Survey, which is based on 20 years of research by the University of Chicago Consortium on Chicago School Research. The survey's five components have been identified as critical to school success. They include, Effective Leaders, Collaborative Teachers, Involved Families, Supportive Environment, and Ambitious Instruction. It is assumed that the feedback given by students and teachers on each of these components provides a "...comprehensive picture of the school environment..." (UChicago Impact, 2015, par. 1-2).

Based on foundational research leading to the development of the 5Essentials, Bryk et al. (2010) conceptualized the five essentials as collective efficacy describing them as "...shared values and social cohesion of a community in responding to local problems that may arise" (p. 192). The essence being that schools are community systems made up of groups of individuals that espouse certain values and norms as a collective. In addition, they have abilities and capacities as a collective to respond to issues that arise in the process of educating students. Currently, the Illinois 5Essentials Survey is used as the appropriate tool to measure the collective efficacy of school communities in Illinois. Although this survey has been in use for a decade, there is limited research focusing on establishing its efficacy, especially in relation to appropriateness in defining the 5Esssentials as the collective efficacy factors that have positive influence on learning environment and student academic outcomes for all school in Illinois.

\section{Conceptual Framework for the Study}

Schools are systems comprised of inputs, throughputs, and outputs, and influenced by internal and external environments (Katz \& Kahn, 1978). Inputs include educators, students, budgets, and resources that come to the schools. Throughputs are the processes used to engage and educate the students, and outputs represent the learning outcomes that students achieve after experiencing the educational processes. While, inputs, throughputs, and outputs as a collective make up the internal environment of the school, the community in which the school is located constitutes the external environment. The external environment influences the school by providing resources and setting expectations for school culture and student and school outcomes. Thus, the culture and climate of a school derives from the interactions between internal and external environments. With over 20 years of research, researchers at the University of Chicago Consortium determined that the culture of a school can be defined by the levels of the practice of the five essential supports (5Essentials). Higher levels of the practice of 5Essentials “...enhance students' engagement with school and improve their 
learning outcomes" (Bryk et al., 2010, p. 46). The 5Essentials are described as follows:

Effective Leaders: The principal works with teachers to implement a clear and strategic vision for school success.

Collaborative Teachers: The staff is committed to the school, receives strong professional development, and works together to improve the school.

Involved Families: The entire school staff builds strong relationships with families and communities to support learning.

Supportive Environment: The school is safe and orderly. Teachers have high expectations for students and support students to realize their goals. Classmates also support one another.

Ambitious Instruction: Classes are academically demanding and engage students by emphasizing the application of knowledge.

(UChicago Impact, 2015, par. 1).

In their research, Bryk et al. (2010) identified Effective Leadership as the major input that drives the vision and change in the school system. Other researchers agree (Ingersoll, et al., 2018; Day \& Gurr, 2014). According to Ingersoll et al. (2018), a key element of effective instructional leadership is developing a shared vision and purpose among the faculty. For the same reason, Day and Gurr (2014) suggest that school leaders set direction with a vision focused on success and how to improve. Because leadership does not exist in a vacuum, Bryk et al. (2010) also discuss other essential supports within the school system. Accordingly, Collaborative Teachers, Supportive Environment, and Involved Families not only interact with each other, they also interact with the classroom (Ambitious Instruction) in a reciprocating relationship in response to school leadership. In other words, although Ambitious Instruction exists solely within the classroom, it is influenced indirectly by the other four essential supports. And therefore, the school system output (defined by student outcomes) is reflective of the practice of the 5Essentials (Bryk et al., 2010, p. 69) (Figure 1).

As described by Bryk et al. (2010) the composite score on the 5Essentials survey gives a sense of group-level attribute (collective efficacy) that represents the shared beliefs about the collective power to execute a course of action that will result in positive impacts on students. Bandura (1977) identifies efficacy as the perceived belief in the ability to achieve a goal in a specific situation. Bandura's (1977) model identifies four experiential sources of efficacy judgement. They include mastery experiences (performing well on a previous task, builds competence), vicarious experience (comparing competence of self to others), verbal persuasion (encouragement or discouragement by others), and emotional arousal (feelings of sensations that communicate belief in ability to achieve). The significance of these experiences is their power to influence perceptions or feelings of the ability to achieve goals which, in turn stimulates continued levels of commitment toward meeting those goals. In a school system, these experiences are likely to inspire sense of self or collective-efficacy in executing the 5Essentials. For this reason, Bryk et al. (2010) explain that collective efficacy is determined by the extent of the collective practice of 5Essentials which, in turn effect student 
achievement. In this study, the 5Essentials and efficacy factors and used synonymously.

Figure 1. Essential Supports for School Reform- 5Essentials and Student Achievement labeled in italics

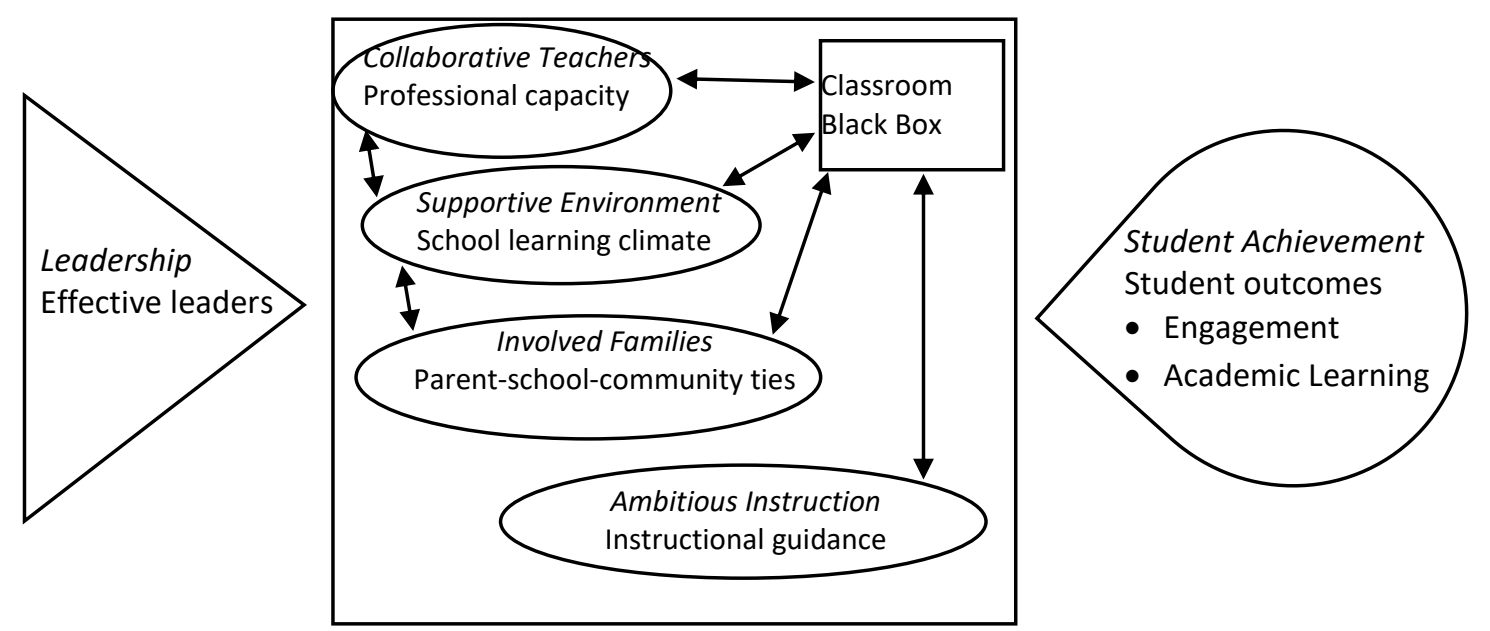

Source: Bryk et al., 2010, p. 69.

Guided by the conceptual framework above, this study examined the relationships among collective efficacy factors, as measured by the Illinois 5Essentials Survey and college readiness scores as reported by ACT for high schools in the state of Illinois. The research questions were: What are the mean scores for collective efficacy factors and high school college readiness measures; What are the relationships between high school college readiness measures and collective efficacy factors; What are the differences based on location (Chicago, suburban, rural) among college readiness measures and collective efficacy factors; and What collective efficacy factors predict college readiness?

\section{Literature Review}

The literature review focuses on research and theories that inform the concept of collective-efficacy. Such theories include social cognitive theory and selfefficacy. Collective efficacy though a new phenomenon that is still developing in the literature has promise because it is grounded in social cognitive theory and self-efficacy.

\section{Social Cognitive Theory}

Social cognitive theory posits the belief that human action and understanding is, in part, a function of observing others within a social situation and using what they have learned (through observation) to make decisions (Bandura, 2001). Social cognitive theory puts greater emphasis on the core features of human agency to “...intentionally make things happen by one's actions" (Bandura, 2001, p. 2). By 
this logic, people do not simply exist as observers of the natural world around them, instead, they use it to create and/or anticipate other experiences. Thus, through interactions with the environment, humans make decisions and gain experiences that facilitate their abilities and proclivities to make future decisions. By setting intentions, people set expectations for outcomes, establish anticipated outcomes and, using acknowledged standards, react to outcomes based upon personal and social standards (Bandura, 2001). Based upon the feedback that the individual receives and the interpretation they make from actions, one will determine capacity for success in similar future endeavors. This supports Bandura's idea of triadic reciprocal causation, in which the individual finds him or herself reflecting upon personal factors, the environment, and their behaviors to determine future decisions and the levels of efficacy towards outcomes of those decisions (Eells, 2011). Social cognitive theory thus forms the basis for selfefficacy and, by extension, collective efficacy.

\section{Self-Efficacy}

The concept of self-efficacy is defined by Hoy et al. (2002) as “...beliefs in one's capabilities to organize and execute a course of action required to produce a given attainment" (p. 78). Flowing from the umbrella of social cognitive theory and human agency, the intentional choices that a person makes to act are influenced by the belief in self to do a task. The belief in self to do the task is what distinguishes self-efficacy from concepts like self-esteem or self-worth.

According to Bandura (1977), there are four informants of efficacy. Mastery or performance accomplishments are, by far, the most powerful informants of efficacy expectations. The more success one experiences, the greater the selfefficacy expectation and the lower the negative impact that failures will have on the person. It is hereby assumed that greater mastery increases chances for persistence, and with that a person finds, through experience, that difficult situations can be overcome.

Another of Bandura's informant of efficacy expectations is vicarious experiences. Watching others engage, especially in threatening situations without adverse consequences can generate efficacy expectations of success in others. While this efficacy information is not as strong as mastery that comes through participant modeling, seeing others succeed shows that even the most anxious can eventually succeed through persistence, and seeing many others succeed is more encouraging than seeing one or none.

In addition to mastery and vicarious experiences, the third source of efficacy expectation is verbal persuasion. Verbal persuasion involves suggestions from outsiders that an individual can be successful. However, just as verbal persuasion can have significantly positive effects in building confidence, it can also have negative ramifications for the receiving individual, especially when competence expectations are raised and conditions for the person to succeed are not right. Not only will the persuader be discredited, the negative experience will further debilitate the recipient's personal efficacy and motivation to persist. 
The fourth source of efficacy expectation identified by Bandura is emotional arousal. The right amount of arousal may energize a person to action, however, higher than necessary emotional arousal generally hampers performance. People are more likely to be successful when they are not experiencing negative arousal situations. Helping people perceive the right levels of self-competence can reduce excessive arousal and can lead to action on the part of the individual if he or she is able to reduce self-doubts. "Performance successes, in turn, strengthens selfefficacy" (Bandura, 1977) and is the beginning of a positive cycle.

In studying effects of self-efficacy, Goddard, Hoy and Woolfolk-Hoy (2004) found that teachers with greater sense of self-efficacy tended to be better prepared to teach, used more innovative strategies in teaching, and tended to be more student centered. Additionally, the concepts of trust, openness, and job satisfaction were found to be related to a teacher's sense of self-efficacy and productivity (student achievement) in the classroom (Goddard et al., 2004).

\section{Collective Teacher Efficacy}

Collective efficacy is growing out of Bandura's $(1977,1993,2001)$ work and is driven by the notion of human agency -people's desire to exercise control over their lives in a variety of ways (Rotter, 1966). When groups of individuals act together to achieve common intentions based on shared beliefs, their individual agencies are extended to collective agency of the organization (Goddard et al., 2000). Goddard, et al. (2000) describe collective teacher efficacy as “...an emergent group-level attribute - the product of the interactive dynamics of the group members" (p. 5). The shared beliefs of the group members influence their capacity to make and act on decisions about desired goals. In the same notion, the collective would be associated with the levels of stress and persistence that organizations feel when targeting and planning to meet achievement outcomes. For instance, in the 15 years that the No Child Left Behind (NCLB) Act was in existence, accountability for student achievement increased and became more consequential. Because of the consequences, schools learned the goals they needed to set to raise student achievement, the policies and procedures they needed to reach these goals, and the resulting changes they needed to make after evaluation of outcomes. This organizational learning occurred as a collective effort by principals, teachers and school boards who made judgments of the faculty's abilities to make improvements in student achievement based on their context.

Like the informants of self-efficacy, organizations use mastery (performance experiences), vicarious experiences, social persuasion, and emotional arousal to strengthen or diminish the motive and capacity of its members to continue their efforts. Schools as organizations use the four experiences to develop a sense of collective efficacy as they work together towards the goals of school improvement and higher student outcomes. Bryke et al. (2010) conceptualized effective leadership, collaborative teachers, involved families, supportive environment, and ambitious instruction as collective efficacy in schools. Together, the functions of these factors reflect the collective engagement of schools' internal and external environments. 


\section{Methodology}

This was a descriptive, one-time cross-sectional study in which different groups were studied at the same time. Electronic data, based on responses from high school teachers and students that are uploaded annually by school districts in the state of Illinois and published annually online via the Illinois School Report Card, were gathered and re-organized by the researchers. Categories of reported data by each school included: county location of the school, city location of the school, percent of low-income students at the school, racial/ethnic diversity of the student population, and the percentage of students who were identified as college ready by meeting or exceeding the American College Testing (ACT) composite benchmark of 21 .

The dependent variable in the study was college readiness composite score as reported from ACT. Independent variables included percentages of students from low-income backgrounds, racial population percentages, and the 5Essentials category scores. The population $(\mathrm{N}=567)$ was public high schools in the state of Illinois whose 2015 data on, among other things, school demographics, school achievement levels, and school environment survey scores were reported by the Illinois School Report Card. The schools included in this study satisfied two criteria:

1. They posted the percentage of students meeting or exceeding a composite score of 21 on the ACT during the 2014-2015 school year, and

2. They had full reports for the Illinois 5Essentials Survey for that same period.

Of the 567 high schools reporting data to the Illinois Interactive Report Card, 379 high schools had full Illinois 5Essentials reports and college readiness reports from the ACT. These 379 schools made the sample $(n)$ for this study.

The 2015 version of the 5Essentials survey is a combination of 80 and 150 questions for student and teachers respectively, compiled into 22 measures of school climate and practices. These 22 measures are distributed among the five essentials categories namely Effective Leadership, Collaborative Teachers, Supportive Environment, Involved Families, and Ambitious Instruction. Each of these categories is rated on the degree of implementation based upon the respondents' answers as follows: Most Implementation, More Implementation, Average Implementation, Less Implementation, Least Implementation. For the purposes of this study, these ratings were assigned a numerical value ranging from 5 (Most Implementation) to 1 (Least Implementation). Reliability coefficients for each of the sub-scales based on the UChicago Consortium of Chicago School ranged from Cronbach's $\alpha=.71$ to .97 , except for one sub-scale, Ambitious Instruction which was Cronbach's $\alpha=.60$ (Klugman, Gordon, Sebring, \& Sporte, 2015). Descriptive statistics, Analysis of Variance (ANOVA), correlations, and regressions were used to analyze data. 


\section{Findings}

\section{Analysis of Mean Score Values}

Table 1 presents descriptive data on demographic variables of income and ethnicity. The results indicate that the largest concentration of schools with significant low-income students is the city of Chicago. Most high schools within Chicago had a high concentration of low-income students clustered closely around the mean (with $68 \%$ of scores falling within one standard deviation above and below the mean).

Table 1. Income and Ethnicity Mean Percentages and Standard Deviation Scores (SD)

\begin{tabular}{|l|c|c|c|c|}
\hline & $\begin{array}{c}\text { All Illinois } \\
\text { High Schools }\end{array}$ & $\begin{array}{c}\text { Chicago High } \\
\text { Schools }\end{array}$ & $\begin{array}{c}\text { Suburban High } \\
\text { Schools }\end{array}$ & $\begin{array}{c}\text { Rural High } \\
\text { Schools }\end{array}$ \\
\hline \% Low & 48.47 & 89.60 & 39.90 & 43.02 \\
Income & $(24.15)$ & $(14.04)$ & $(24.06)$ & $(16.29)$ \\
\hline \% White & 68.14 & 6.86 & 53.16 & 85.78 \\
& $(34.18)$ & $(11.45)$ & $(29.31)$ & $(18.22)$ \\
\hline \% African & 13.79 & 50.29 & 16.58 & 5.38 \\
American & $(26.25)$ & $(39.91)$ & $(26.08)$ & $(13.04)$ \\
\hline \% Hispanic & 13.20 & 38.27 & 22.20 & 5.03 \\
& $(21.00)$ & $(34.63)$ & $(19.84)$ & $(9.15)$ \\
\% Asian & 2.09 & 3.25 & 5.06 & .84 \\
\hline \% American & $(4.21)$ & $(5.42)$ & $(6.58)$ & $(1.40)$ \\
Ind. & .23 & .23 & .30 & .21 \\
\hline \% 2+ Races & $(.30)$ & $.93)$ & $(.27)$ & $(.31)$ \\
\hline \% Pacific & 2.35 & $(.99)$ & $(1.35)$ & 2.60 \\
Island. & $(2.03)$ & .12 & .08 & $(2.26)$ \\
\hline Sample Size & $(.08$ & $n=50$ & $n=84$ & $n$ \\
\hline
\end{tabular}

The largest population of schools with African American and Hispanic populations are also found in the Chicago sub-group. High schools in Chicago tended to have greater variance in African American and Hispanic populations ( $M$ $=50.29 \%, S D=39.91$ and $M=38.27 \%, S D=34.63$, respectively). High schools with large White populations were found in rural areas, representing the largest sub-group $(n=245)$.

Table 2 presents mean percentages and standard deviations for college readiness measures. Suburban high schools achieved the highest mean score values across all areas of college readiness measures. High schools in Chicago had the lowest percentage of students meeting or exceeding each of these benchmark requirements. However, observing the standard deviations for these percentages, the Chicago group of high schools had a larger spread of scores compared to suburban and rural schools. 
Table 2. College Readiness Mean Percentages and Standard Deviation Scores (SD)

\begin{tabular}{|l|c|c|c|c|}
\hline & $\begin{array}{c}\text { All Illinois } \\
\text { High Schools }\end{array}$ & $\begin{array}{c}\text { Chicago High } \\
\text { Schools }\end{array}$ & $\begin{array}{c}\text { Suburban High } \\
\text { Schools }\end{array}$ & $\begin{array}{c}\text { Rural High } \\
\text { Schools }\end{array}$ \\
\hline \% College & 39.53 & 18.94 & 47.74 & 40.91 \\
Readiness & $(18.45)$ & $(22.76)$ & $(20.67)$ & $(12.88)$ \\
\hline \% English CRB & 56.80 & 36.82 & 62.85 & 58.81 \\
& $(17.60)$ & $(23.72)$ & $(18.05)$ & $(12.56)$ \\
\hline \% Math CRB & 32.75 & 15.30 & 41.56 & 33.29 \\
& $(17.54)$ & $(20.37)$ & $(19.68)$ & $(13.12)$ \\
\hline CRB Reading & 34.34 & 15.72 & 41.01 & 35.85 \\
\% Science CRB & $(16.12)$ & $(20.14)$ & $(17.60)$ & $(11.27)$ \\
\hline \% All 4 CRB & 29.54 & 13.30 & 37.20 & 30.23 \\
& $(15.62)$ & $(18.32)$ & $(18.16)$ & $(11.13)$ \\
\hline Sample Size & 19.09 & 7.38 & 26.38 & 18.99 \\
\hline
\end{tabular}

Table 3 displays the mean values for the collective efficacy factors gathered through the Illinois 5Essentials Survey. Scores were grouped around the mid-point of the 1-5 scale, thus 3. The factor of Effective Leaders generated the lowest score, while the factor of Ambitious Instruction had the highest mean score for each subgroup. In this study, teachers and students reported great confidence in levels of instruction and presented the least confidence in the effectiveness of school leadership. The degree of standard deviation for collective efficacy factors is very small, as would be expected when observing many 5-point Likert-type scores. However, it is significant to note that the smallest variance is found among Suburban High Schools $(n=84)$ in the efficacy factor of Ambitious Instruction $(S D=.57)$.

Table 3. Collective Efficacy Mean Values and Standard Deviation Scores (SD)

\begin{tabular}{|l|c|c|c|c|}
\hline & $\begin{array}{c}\text { All Illinois } \\
\text { High Schools }\end{array}$ & $\begin{array}{c}\text { Chicago High } \\
\text { Schools }\end{array}$ & $\begin{array}{c}\text { Suburban High } \\
\text { Schools }\end{array}$ & $\begin{array}{c}\text { Rural High } \\
\text { Schools }\end{array}$ \\
\hline Effective & 2.73 & 3.02 & 2.49 & 2.75 \\
Leaders & $(.77)$ & $(.80)$ & $(.77)$ & $(.75)$ \\
\hline Collaborative & 3.05 & 3.42 & 3.20 & 2.92 \\
Teachers & $(.83)$ & $(.84)$ & $(.83)$ & $(.80)$ \\
\hline Supportive & 3.03 & 3.32 & 3.18 & 2.91 \\
Environment & $(.77)$ & $(.74)$ & $(.84)$ & $(.72)$ \\
\hline Ambitious & 3.27 & 3.66 & 3.48 & 3.12 \\
Instruction & $(.72)$ & $(.72)$ & $(.57)$ & $(.73)$ \\
\hline Involved & 3.05 & 3.36 & 3.29 & 2.91 \\
Families & $(.86)$ & $(.88)$ & $(.95)$ & $(.79)$ \\
\hline Average & 3.03 & 3.36 & 3.13 & 2.92 \\
Collective & $(.79)$ & $(.80)$ & $(.79)$ & $(.76)$ \\
Efficacy & $n=379$ & $n=50$ & $n=84$ & $n=245$ \\
\hline Sample Size & \multicolumn{3}{|}{}
\end{tabular}




\section{Differences by Location among Collective Efficacy Factors and College Readiness Measures}

To determine if there existed statistically significant differences in collective efficacy factors and college readiness measures by location, a series of one-way ANOVA tests were conducted. In each case, Post Hoc testing was done to determine where significant mean differences were. With unequal sample sizes, the Scheffe test was used.

ANOVA compared the collective efficacy factor of Effective Leadership among three groupings of high schools (Chicago, suburban, and rural). The analysis found statistically significant differences, $F(2,376)=7.98, p<.001$, but the strength of the difference, $\eta^{2}=.04$, was weak. Post Hoc testing revealed significant difference between Chicago and suburban high schools, $F(2,376)=$ $7.66, p<.01$, and between suburban and Rural high schools, $F(2,376)=3.61, p<$ .05 . ANOVA results are presented in Table 4.

Table 4. One-Way Analysis of Variance of Effective Leadership among Chicago, Suburban and Rural High Schools

\begin{tabular}{|l|c|c|c|c|c|c|}
\hline Source & $\boldsymbol{d} \boldsymbol{f}$ & $\boldsymbol{S S}$ & $\boldsymbol{M S}$ & $\boldsymbol{F}$ & $\boldsymbol{p}$ & $\boldsymbol{\eta}^{2}$ \\
\hline Between groups & 2 & 9.18 & 4.59 & 7.98 & .00 & .04 \\
\hline Within groups & 376 & 216.28 & .58 & & & \\
\hline Total & 378 & 225.46 & & & & \\
\hline
\end{tabular}

Completing an analysis of the variance on Collaborative Teachers among Chicago, suburban and rural high schools showed a significant difference, $F(2$, $376)=9.96, p<.001$. The strength of the difference, calculated by $\eta^{2}$, was .05 (Table 5). Post Hoc testing showed statistical differences between Chicago and rural high schools, $F(2,376)=8.04, p<.01$, and between suburban and rural high schools $F(2,376)=3.87, p<.05$. The strengths of these relationships were found to be $\eta^{2}=.04$ and $\eta^{2}=.02$, with the statistical differences between Chicago and rural schools being larger.

Table 5. One-Way Analysis of Variance of Collaborative Teachers among Chicago, Suburban and Rural High Schools

\begin{tabular}{|l|c|c|c|c|c|c|}
\hline Source & $\boldsymbol{d} \boldsymbol{f}$ & $\boldsymbol{S S}$ & $\boldsymbol{M S}$ & $\boldsymbol{F}$ & $\boldsymbol{p}$ & $\boldsymbol{\eta}^{\mathbf{2}}$ \\
\hline Between groups & 2 & 13.04 & 6.52 & 9.96 & .000 & .05 \\
\hline Within groups & 376 & 246.11 & .65 & & & \\
\hline Total & 378 & 259.15 & & & & \\
\hline
\end{tabular}

Table 6 shows the results for the ANOVA for the collective efficacy factor of Supportive Environment among Chicago, suburban, and rural high schools. Analysis found a statistically significant difference among these groups, $F(2,376)$ $=8.26, p<.01$. The strength of the difference, as calculated by $\eta^{2}$, was .04 . Post Hoc testing found statistically significant differences between Chicago and rural high schools, $F(2,376)=6.11, p<.01$, and between suburban and rural high 
schools, $F(2,376)=3.91, p<.05$. The strengths of these differences were both weak, $\eta^{2}=.03$ and $\eta^{2}=.02$, respectively.

Table 6. One-Way Analysis of Variance of Supportive Environment among Chicago, Suburban and Rural High Schools

\begin{tabular}{|l|c|c|c|c|c|c|}
\hline Source & $\boldsymbol{d} \boldsymbol{f}$ & $\boldsymbol{S S}$ & $\boldsymbol{M S}$ & $\boldsymbol{F}$ & $\boldsymbol{p}$ & $\boldsymbol{\eta}^{\mathbf{2}}$ \\
\hline Between groups & 2 & 9.33 & 4.67 & 8.26 & .000 & .04 \\
\hline Within groups & 376 & 212.40 & .56 & & & \\
\hline Total & 378 & 221.74 & & & & \\
\hline
\end{tabular}

Analysis of variance was conducted for Ambitious Instruction among Chicago, suburban and rural high schools (Table 7). A statistically significant difference was found, $F(2,376)=17.39, p<.01$, with the strength of the difference determined at $\eta^{2}=.08$. Post Hoc analysis indicated differences exist between Chicago and Rural high schools, $F(2,376)=12.69, p<.01, \eta^{2}=.06$, and between Suburban and Rural high schools, $F(2,376)=8.35, p<.01, \eta^{2}=.04$.

Table 7. One-Way Analysis of Variance of Ambitious Instruction among Chicago, Suburban and Rural High Schools

\begin{tabular}{|l|c|c|c|c|c|c|}
\hline Source & $\boldsymbol{d} \boldsymbol{f}$ & $\boldsymbol{S S}$ & $\boldsymbol{M S}$ & $\boldsymbol{F}$ & $\boldsymbol{p}$ & $\boldsymbol{\eta}^{2}$ \\
\hline Between groups & 2 & 16.81 & 8.40 & 17.39 & .000 & .08 \\
\hline Within groups & 376 & 181.74 & .48 & & & \\
\hline Total & 378 & 198.55 & & & & \\
\hline
\end{tabular}

ANOVA was conducted on collective efficacy factor, Involved Families. Among the three groupings of Chicago, suburban and rural high schools, the analysis found statistically significant difference, $F(2,376)=10.38, p<.01, \eta^{2}=$ .05 (Table 8). In Post Hoc testing, statistical significance in group differences were found between suburban and rural high schools, $F(2,376)=6.44, p<.01, \eta^{2}=.03$, and between Chicago and rural high schools, $F(2,376)=199.89, p<.01, \eta^{2}=$ 1.00. As noted, this last test presented an effect size of 1.00 .

Table 8. One-Way Analysis of Variance of Involved Families among Chicago, Suburban and Rural High Schools

\begin{tabular}{|l|c|c|c|c|c|c|}
\hline Source & $\boldsymbol{d} \boldsymbol{f}$ & $\boldsymbol{S S}$ & $\boldsymbol{M S}$ & $\boldsymbol{F}$ & $\boldsymbol{p}$ & $\boldsymbol{\eta}^{\mathbf{2}}$ \\
\hline Between groups & 2 & 14.54 & 7.27 & 10.38 & 0.00 & .05 \\
\hline Within groups & 376 & 263.50 & .70 & & & \\
\hline Total & 378 & 278.05 & & & & \\
\hline
\end{tabular}

Finally, ANOVA was conducted to analyze the differences among Chicago, suburban and rural high schools in college readiness means for percentage of students who meet the college readiness ACT benchmark of 21. Statistically significant differences (Table 9) were found among the three groups, $F(2,376)=$ 50.68, $p<.01, \eta^{2}=.21$. Post Hoc analysis showed statistically significant differences between Chicago and suburban schools, $F(2,376)=48.22, p<.01, \eta^{2}$ $=.20$; between Chicago and rural schools, $F(2,376)=37.18, p<.01, \eta^{2}=.16$; and 
between suburban and rural schools, $F(2,376)=5.41, p<.01, \eta^{2}=.02$. Table 10 presents results of Post Hoc analysis.

Table 9. One-Way Analysis of Variance of College Readiness Measures among Chicago, Suburban and Rural High Schools

\begin{tabular}{|l|c|c|c|c|c|c|}
\hline Source & $\boldsymbol{d} \boldsymbol{f}$ & $\boldsymbol{S S}$ & $\boldsymbol{M S}$ & $\boldsymbol{F}$ & $\boldsymbol{p}$ & $\boldsymbol{\eta}^{2}$ \\
\hline Between groups & 2 & 27323.43 & 13661.71 & 50.68 & .000 & .21 \\
\hline Within groups & 376 & 101351.08 & 269.55 & & & \\
\hline Total & 378 & 128674.51 & & & & \\
\hline
\end{tabular}

Table 10. Summary of Scheffe Post Hoc Test of College Readiness Measures among Chicago, Suburban and Rural High Schools

\begin{tabular}{|l|c|c|c|}
\hline Pair tested & $\mathbf{F}$ & $\mathbf{F}_{\text {crit }}$ & $\mathbf{\eta}^{\mathbf{2}}$ \\
\hline $\begin{array}{l}\text { Chicago X } \\
\text { Suburban }\end{array}$ & $48.22^{*}$ & 4.66 & .20 \\
\hline Chicago X Rural & $37.18^{*}$ & 4.66 & .16 \\
\hline Suburban X Rural & $5.41^{*}$ & 4.66 & .02 \\
\hline
\end{tabular}

$* p<.01$

\section{Correlation of College Readiness Measures and Collective Efficacy Factors}

Correlation analyses were performed on college readiness composite scores and the Illinois 5Essentials factors of Effective Leaders, Collaborative Teachers, Involved Families, Supportive Environment and Ambitious Instruction. The strongest relationship with college readiness was found between college readiness and Involved Families $(r=.49, p=.01)$, whereas the weakest relationship was found between college readiness and Effective Leaders $(r=.11, p=.05)$. This data is presented in Table 11.

Table 11. Correlations among College Readiness and Collective Efficacy Factors for Illinois High Schools $(\mathrm{n}=379)$

\begin{tabular}{|l|c|c|c|c|c|c|}
\hline & $\begin{array}{c}\text { College } \\
\text { Readiness }\end{array}$ & $\begin{array}{c}\text { Effective } \\
\text { Leaders }\end{array}$ & $\begin{array}{c}\text { Collaborative } \\
\text { Teachers }\end{array}$ & $\begin{array}{c}\text { Supportive } \\
\text { Environment }\end{array}$ & $\begin{array}{c}\text { Ambitious } \\
\text { Instruction }\end{array}$ & $\begin{array}{c}\text { Involved } \\
\text { Families }\end{array}$ \\
\hline $\begin{array}{l}\text { Effective } \\
\text { Leaders }\end{array}$ & .11 & 1 & & & & \\
\hline $\begin{array}{l}\text { Collaborative } \\
\text { Teachers }\end{array}$ & .22 & $.68^{* *}$ & 1 & & & \\
\hline $\begin{array}{l}\text { Supportive } \\
\text { Environment }\end{array}$ & $.42^{* *}$ & $.46^{* *}$ & $.51^{* *}$ & 1 & & \\
\hline $\begin{array}{l}\text { Ambitious } \\
\text { Instruction }\end{array}$ & $.23^{* *}$ & $.29^{* *}$ & $.41^{* *}$ & $.59^{* *}$ & 1 & \\
\hline $\begin{array}{l}\text { Involved } \\
\text { Families }\end{array}$ & $.49^{* *}$ & $.50^{* *}$ & $.66^{* *}$ & $.61^{* *}$ & $.45^{* *}$ & 1 \\
\hline
\end{tabular}

Note: $* p<.05$, one-tail. $* * p<.01$, one-tail.

Looking deeper at the relationships among college readiness and demographic factors (percentage of low-income students and the percentage of ethnic minorities), the results indicate a statistically significant, strong negative correlation between the percentage of low-income students and college readiness $(r=-.82, p$ 
$<.01)$. Additionally, we found statistically significant correlations by percentage of the ethnic groupings and college readiness. Among the ethnic groups, the strongest relationship was a negative correlation between percentage of African American students and college readiness $(\mathrm{r}=-.53, \mathrm{P}<.01)$. Table 12 presents this data.

Among the regional sub-groups of Chicago, suburban, and rural schools, each group showed statistically significant moderate relationships with college readiness $(r=.31, p<.01 ; r=.64, p<.01 ; r=.26, p<.01$, respectively). The suburban schools and rural schools produced their weakest relationships among college readiness and Effective Leaders $(r=.46, p<.01$ and $r=.14, p>.05$, respectively), while the Chicago schools exhibited the weakest relationship among college readiness and Collaborative Teachers $(r=.09, p>.05)$. This was, however, closely followed by college readiness and Effective Leaders $(r=.14, p>$ .05). The Pearson correlations between pairs of variables are presented in Tables 13 through 15.

Table 12. Correlations among Percentage Low Income/ Ethnicity and College Readiness for Illinois High Schools $(\mathrm{n}=379)$

\begin{tabular}{|l|c|}
\hline & College Readiness \\
\hline \% White & $.52^{* *}$ \\
\hline \% African American & $-.53^{* *}$ \\
\hline \% Hispanic & $-.27^{* *}$ \\
\hline \% Asian & $.36^{* *}$ \\
\hline \% Low Income & $-.82^{* *}$ \\
\hline
\end{tabular}

$* p<.05$, one-tail. $* * p<.01$, one-tail.

Table 13. Correlations among College Readiness and Collective Efficacy Factors in Chicago Schools $(\mathrm{n}=50)$

\begin{tabular}{|l|c|c|c|c|c|c|}
\hline & $\begin{array}{c}\text { College } \\
\text { Readiness }\end{array}$ & $\begin{array}{c}\text { Effective } \\
\text { Leaders }\end{array}$ & $\begin{array}{c}\text { Collaborative } \\
\text { Teachers }\end{array}$ & $\begin{array}{c}\text { Supportive } \\
\text { Environment }\end{array}$ & $\begin{array}{c}\text { Ambitious } \\
\text { Instruction }\end{array}$ & $\begin{array}{c}\text { Involved } \\
\text { Families }\end{array}$ \\
\hline $\begin{array}{l}\text { Effective } \\
\text { Leaders }\end{array}$ & .14 & 1 & & & & \\
\hline $\begin{array}{l}\text { Collaborative } \\
\text { Teachers }\end{array}$ & .09 & $.82^{* *}$ & 1 & & & \\
\hline $\begin{array}{l}\text { Supportive } \\
\text { Environment }\end{array}$ & $.57^{* *}$ & $.47^{* *}$ & $.41^{* *}$ & 1 & & \\
\hline $\begin{array}{l}\text { Ambitious } \\
\text { Instruction }\end{array}$ & $.52^{* *}$ & $.41^{* *}$ & $.35^{* *}$ & $.75^{* *}$ & 1 & \\
\hline $\begin{array}{l}\text { Involved } \\
\text { Families }\end{array}$ & $.56^{* *}$ & $.61^{* *}$ & $.51^{* *}$ & $.61^{* *}$ & $.49^{* *}$ & 1 \\
\hline
\end{tabular}


Table 14. Correlations among College Readiness and Collective Efficacy Factors I

Suburban Schools $(\mathrm{n}=84)$

\begin{tabular}{|l|c|c|c|c|c|c|}
\hline & $\begin{array}{c}\text { College } \\
\text { Readiness }\end{array}$ & $\begin{array}{c}\text { Effective } \\
\text { Leaders }\end{array}$ & $\begin{array}{c}\text { Collaborative } \\
\text { Teachers }\end{array}$ & $\begin{array}{c}\text { Supportive } \\
\text { Environment }\end{array}$ & $\begin{array}{c}\text { Ambitious } \\
\text { Instruction }\end{array}$ & $\begin{array}{c}\text { Involved } \\
\text { Families }\end{array}$ \\
\hline $\begin{array}{l}\text { Effective } \\
\text { Leaders }\end{array}$ & $.46^{* *}$ & 1 & & & & \\
\hline $\begin{array}{l}\text { Collaborative } \\
\text { Teachers }\end{array}$ & $.62 * *$ & $.73^{* *}$ & 1 & & & \\
\hline $\begin{array}{l}\text { Supportive } \\
\text { Environment }\end{array}$ & $.81^{* *}$ & $.57^{* *}$ & $.74 * *$ & 1 & & \\
\hline $\begin{array}{l}\text { Ambitious } \\
\text { Instruction }\end{array}$ & $.48^{* *}$ & $.48^{* *}$ & $.53^{* *}$ & $.55^{* *}$ & 1 & \\
\hline $\begin{array}{l}\text { Involved } \\
\text { Families }\end{array}$ & $.80^{* *}$ & $.58^{* *}$ & $.72^{* *}$ & $.72^{* *}$ & $.55^{* *}$ & 1 \\
\hline
\end{tabular}

$* p<.05$, one-tail. $* * p<.01$, one-tail.

Table 15. Correlations among College Readiness and Collective Efficacy Factors in Rural Schools (245)

\begin{tabular}{|l|c|c|c|c|c|c|}
\hline & $\begin{array}{c}\text { College } \\
\text { Readiness }\end{array}$ & $\begin{array}{c}\text { Effective } \\
\text { Leaders }\end{array}$ & $\begin{array}{c}\text { Collaborative } \\
\text { Teachers }\end{array}$ & $\begin{array}{c}\text { Supportive } \\
\text { Environment }\end{array}$ & $\begin{array}{c}\text { Ambitious } \\
\text { Instruction }\end{array}$ & $\begin{array}{c}\text { Involved } \\
\text { Families }\end{array}$ \\
\hline $\begin{array}{l}\text { Effective } \\
\text { Leaders }\end{array}$ & .14 & 1 & & & & \\
\hline $\begin{array}{l}\text { Collaborative } \\
\text { Teachers }\end{array}$ & $.26^{* *}$ & $.67^{* *}$ & 1 & & & \\
\hline $\begin{array}{l}\text { Supportive } \\
\text { Environment }\end{array}$ & $.37^{* *}$ & $.43^{* *}$ & $.40^{* *}$ & 1 & & \\
\hline $\begin{array}{l}\text { Ambitious } \\
\text { Instruction }\end{array}$ & $.26^{* *}$ & $.24 * *$ & $.33^{* *}$ & $.54 * *$ & 1 & \\
\hline $\begin{array}{l}\text { Involved } \\
\text { Families }\end{array}$ & $.51^{* *}$ & $.49^{* *}$ & $.64 * *$ & $.52^{*}$ & $.36^{*}$ & 1 \\
\hline
\end{tabular}

${ }^{*} p<.05$, one-tail. $* * p<.01$, one-tail.

\section{Predicting College Readiness Using Collective Efficacy Factors}

Multiple linear regression was conducted on the full sample to predict college readiness scores based on the collective efficacy factors of Effective Leaders, Collaborative Teachers, Supportive Environment, Ambitious Instruction and Involved Families. A significant regression equation was found $[F(5,373)=33.41$, $p<.05$ ], with an Adjusted $\mathrm{R}^{2}$ of .30 . Table 16 provides a full summary output of this regression.

Only three of the five collective efficacy factors (Effective Leaders, Supportive Environment, and Involved Families) were found to meet a minimum significance level $(p<.05)$ acceptable to this study. Another regression was run with the remaining significant variables and Step 2 shows these results. A final regression was run with the two variables (Supportive Environment and Involved Families) with beta values demonstrating positive impact on the relationship with the constant (college readiness scores). Step 3 of Table 16 displays the results of this regression. In this instance, and with the removal of Effective Leaders as an influencing variable, Supportive Environment and Involved Families produced a 
statistically significant regression equation $[F(1,375)=19.93, p<.001]$, with an Adjusted $\mathrm{R}^{2}$ of .26 .

Similar regression analysis was conducted to examine the predictive qualities of collective efficacy on college readiness based upon location. Tables 17, 18 and 19 display the data output from these regressions for collective efficacy factors meeting a minimum level of significance of $p<.05$.

Table 16. Summary of Regression Analysis of Collective Efficacy Factors Predicting College Readiness for Illinois High Schools $(\mathrm{n}=379)$

\begin{tabular}{|l|c|c|c|}
\hline Variable & $\boldsymbol{B}$ & $\boldsymbol{S E} \boldsymbol{B}$ & B \\
\hline Step 1 & & & \\
\hline Constant & 9.89 & 4.18 & \\
\hline Effective Leaders & -4.33 & 1.42 & $-.18^{*}$ \\
\hline Collaborative Teachers & -2.36 & 1.53 & -.11 \\
\hline Supportive Environment & 7.11 & 1.49 & $.30^{* *}$ \\
\hline Ambitious Instruction & -1.78 & 1.38 & -.07 \\
\hline Involved Families & 10.80 & 1.36 & $.50^{* *}$ \\
\hline Step 2 & & & \\
\hline Constant & 6.45 & 3.67 & \\
\hline Effective Leaders & -5.45 & 1.22 & $-.23^{* *}$ \\
\hline Supportive Environment & 6.09 & 1.34 & $.25^{* *}$ \\
\hline Involved Families & 9.67 & 1.23 & $.45^{* *}$ \\
\hline Step 3 & & & \\
\hline Constant & .894 & 3.54 & \\
\hline Supportive Environment & 4.77 & 1.34 & $.20^{* *}$ \\
\hline Involved Families & 7.93 & 1.20 & $.37^{* *}$ \\
\hline
\end{tabular}

Note: $R^{2}=.31$ for Step $1, \Delta R^{2}=-.01$ for Step $2(p=.10), \Delta R^{2}=-.04$ for Step $3(p<.001)$. $* p<.05 . * * p<.001$.

Table 17 shows the results of a regression analysis conducted to predict the influence of collective efficacy factors on college readiness scores at Chicago high schools. In the first step, a statistically significant regression line equation was found $[F(5,44)=9.48, p<.001]$ with an Adjusted $\mathrm{R}^{2}$ of .46 . Finding only one collective efficacy factor (Involved Families) to be statistically significant within this sub-group, a second regression was conducted with a statistically significant equation line $[F(1,48)=22.49, p<.001]$ and an Adjusted $\mathrm{R}^{2}$ value of .31 , indicating that this factor alone accounts for $31 \%$ of the variance in college readiness scores in Chicago high schools

Table 18 presents a summary of regression analysis data for significant collective efficacy factors predicting college readiness in suburban high schools. The analysis found a statistically significant regression equation line $[F(5,78)=$ 52.91, $p<.001]$ and an Adjusted $\mathrm{R}^{2}$ of .76. The two factors, Supportive Environment and Involved Families, were found to be statistically significant and a second regression analysis was conducted which removed the influence of Effective Leaders, Collaborative Teachers and Ambitious Instruction from the model. Step 2 of Table 20 shows the results of this analysis that resulted in a 
statistically significant regression line $[F(2,81)=126.54, p<.001]$ and an Adjusted $\mathrm{R}^{2}$ of .75 .

Table 17. Summary of Regression Analysis of Collective Efficacy Factors Predicting College Readiness in Chicago High Schools $(\mathrm{n}=50)$

\begin{tabular}{|l|c|c|c|}
\hline Variable & $\boldsymbol{B}$ & $\boldsymbol{S E} \boldsymbol{B}$ & $\boldsymbol{\beta}$ \\
\hline Step 1 & & & \\
\hline Constant & -43.08 & 13.81 & \\
\hline Effective Leaders & -7.83 & 5.63 & -.27 \\
\hline Collaborative Teachers & -4.15 & 4.95 & -.15 \\
\hline Supportive Environment & 8.46 & 5.33 & .28 \\
\hline Ambitious Instruction & 9.79 & 5.01 & .21 \\
\hline Involved Families & 13.96 & 3.84 & $.54^{* *}$ \\
\hline Step 2 & & & \\
\hline Constant & -30.41 & 10.75 & \\
\hline Involved Families & 14.69 & 3.10 & $.57^{* *}$ \\
\hline
\end{tabular}

Note: $R^{2}=.52$ for Step $1, \Delta R^{2}=-.20$ for Step $2(p<.05) . * * p<.001$.

Table 18. Summary of Regression Analysis of Collective Efficacy Factors Predicting College Readiness in Suburban High Schools $(\mathrm{n}=84)$

\begin{tabular}{|l|c|c|c|}
\hline Variable & $\boldsymbol{B}$ & $\boldsymbol{S E} \boldsymbol{B}$ & $\boldsymbol{\beta}$ \\
\hline Step 1 & & & \\
\hline Constant & -17.40 & 6.97 & -.08 \\
\hline Effective Leaders & -2.08 & 2.16 & -.12 \\
\hline Collaborative Teachers & -2.95 & 2.51 & $.57^{* *}$ \\
\hline $\begin{array}{l}\text { Supportive } \\
\text { Environment }\end{array}$ & 14.129 & 2.21 & -.03 \\
\hline Ambitious Instruction & -.96 & 2.47 & $.54^{* *}$ \\
\hline Involved Families & 11.62 & 1.88 & \\
\hline Step 2 & & & $.48^{* *}$ \\
\hline Constant & -22.63 & 4.59 & $.46^{* *}$ \\
\hline $\begin{array}{l}\text { Supportive } \\
\text { Environment }\end{array}$ & 11.93 & 1.95 & \\
\hline Involved Families & 9.88 & 1.72 & \\
\hline
\end{tabular}

Note: $R^{2}=.76$ for Step $1, \Delta R^{2}=-.02$ for Step $2(p=.18) . * * p<.001$.

Table 19 provides a summary of results for a regression analysis of statistically significant collective efficacy factors in rural high schools. Again, multiple steps were taken in this analysis to attempt to determine the collective efficacy factors with the greatest predictive influence on college readiness scores for rural high schools. In the initial regression, all five collective efficacy factors accounted for $31 \%$ of the variance in the test $\left[R^{2}=.31, F(5,239)=21.14\right]$, with an Adjusted $\mathrm{R}^{2}$ value of .29. Three collective efficacy factors (Effective Leaders, Supportive Environment and Involved Families) were found to meet a minimum significance threshold of $p<.05$. These three factors accounted for $31 \%$ of the variance in the test $\left[R^{2}=.31, F(3,241)=35.33, p<.001\right]$, with an Adjusted $\mathrm{R}^{2}$ value of .30 . As with the regression analysis of the full sample of Illinois high schools, a third 
regression was run for the two variables (Supportive Environment and Involved Families) with beta values demonstrating positive impact on the relationship with the constant (college readiness scores). In this step of the model, the two factors accounted for $28 \%$ of the variance in the test $\left[R^{2}=.28, F(2,242)=46.67, p<\right.$ $.001]$, with an Adjusted $\mathrm{R}^{2}$ value of .27 . The summary of regression statistics is presented in Table 19.

Table 19. Summary of Regression Analysis of All Collective Efficacy Factors Predicting College Readiness in Rural High Schools $(\mathrm{n}=245)$

\begin{tabular}{|c|c|c|c|}
\hline Variable & $B$ & $S E B$ & $\boldsymbol{\beta}$ \\
\hline \multicolumn{4}{|l|}{ Step 1} \\
\hline Constant & 15.23 & 3.73 & \\
\hline Effective Leaders & -3.03 & 1.29 & $-.18^{*}$ \\
\hline Collaborative Teachers & -.62 & 1.36 & -.04 \\
\hline $\begin{array}{l}\text { Supportive } \\
\text { Environment }\end{array}$ & 3.17 & 1.29 & $.18^{*}$ \\
\hline Ambitious Instruction & .61 & 1.15 & .04 \\
\hline Involved Families & 8.48 & 1.24 & $.52 * *$ \\
\hline \multicolumn{4}{|l|}{ Step 2} \\
\hline Constant & 15.88 & 3.34 & \\
\hline Effective Leaders & -3.35 & 1.09 & $-.19 *$ \\
\hline $\begin{array}{l}\text { Supportive } \\
\text { Environment }\end{array}$ & 3.48 & 1.15 & $.20 *$ \\
\hline Involved Families & 8.29 & 1.10 & $.51 * *$ \\
\hline \multicolumn{4}{|l|}{ Step 3} \\
\hline Constant & 12.48 & 3.21 & \\
\hline $\begin{array}{l}\text { Supportive } \\
\text { Environment }\end{array}$ & 2.65 & 1014 & $.15^{*}$ \\
\hline Involved Families & 7.13 & 1.05 & $.44 * *$ \\
\hline
\end{tabular}

Note: $R^{2}=.31$ for Step $1, \Delta R^{2}=-.00$ for Step $2(p=.81), \Delta R^{2}=-.03$ for Step $3(p<.05)$. $* p<.05 . * * p<.001$.

As a final examination of the data, regression analysis was performed to determine if the percentage of low-income students in school, or the percentage of a specific ethnic group, could predict college readiness. A statistically significant regression equation was found $[F(8,370)=125.47, p<.001]$, with an Adjusted $\mathrm{R}^{2}$ of .73. Two variables were found to meet the required level of significance for this study ( $p<.05)$ : \% Low Income and \% Asian. A second regression was conducted and a statistically significant regression equation was constructed $[F(2,376)=$ 489.76, $p<.001$ ], with an Adjusted $\mathrm{R}^{2}$ of .72. Table 20 displays these results. 
Table 20. Summary of Regression Analysis of Demographic Data Predicting College Readiness for Illinois High Schools $(\mathrm{n}=379)$

\begin{tabular}{|c|c|c|c|}
\hline Variable & $\boldsymbol{B}$ & $S E B$ & $\boldsymbol{\beta}$ \\
\hline \multicolumn{4}{|l|}{ Step 1} \\
\hline Constant & 31.80 & 46.76 & \\
\hline$\%$ Low Income & -.60 & .04 & $-.79 * * *$ \\
\hline$\%$ White & .33 & .47 & .61 \\
\hline$\%$ African American & .32 & .47 & .45 \\
\hline \% Hispanic & .38 & .47 & .43 \\
\hline$\%$ Asian & 1.28 & .49 & $.29 * *$ \\
\hline \% American Indian & 2.54 & 1.82 & .04 \\
\hline$\% 2+$ Races & .87 & .54 & .10 \\
\hline$\%$ Pacific Islander & .42 & 2.92 & .00 \\
\hline \multicolumn{4}{|l|}{ Step 2} \\
\hline Constant & 66.24 & 1.20 & \\
\hline \% Low Income & -.60 & .02 & $-.78 * * *$ \\
\hline$\%$ Asian & 1.04 & .12 & $.24 * * *$ \\
\hline
\end{tabular}

Note: $R^{2}=.73$ for Step $1, \Delta R^{2}=-.008$ for Step $2(p<.001) .{ }^{*} p<.05 .{ }^{* *} p<.01 . * * * p<.001$.

\section{Discussion}

At the beginning of this study, the suggested framework (systems theory) was used to hypothesize the relationships among collective efficacy factors and student achievement. In this framework, Effective Leaders, or leadership, was viewed as the driving force for organizational change and reform in schools (Bryk et al., 2010). Indeed, research has reported the importance of strong leadership to school improvement. For example, Calik, Sezgin, Kavgaci and Kilinc (2012) found there to be a significant relationship between effective instructional leadership (as perceived by teachers) and collective efficacy of teachers. Ingersoll et al. (2018) claimed that good school leadership is tied to higher student achievement. Leithwood and Jantzi (1999) found that principals impact student engagement. However, data in this study shows minimal positive and sometimes negative correlations between leadership and student achievement, especially in comparison to other efficacy factors. Effective Leaders consistently demonstrated lower correlations with student achievement even though it had the highest correlations with Collaborative Teachers. Despite this finding, Collaborative Teachers also consistently demonstrated lower correlations with student achievement compared to Supportive Environment and Involved Families.

Studies indicate that leaders provide vision and direction for their organization to operate, ensure effective and efficient use of resources, and produce needed outcomes (Ingersoll et al., 2018; Day \& Gurr, 2014; Leithwood \& Jantzi, 1999). Ross and Gray (2006) found that transformational leadership has positive impact on teacher collective efficacy and, as a result on increasing the perceived capacity of teachers to improve student achievement. These findings suggest an indirect effect of leaders on student achievement gains. Indirect effects may explain the minimal and weak correlation results found between Effective Leaders and student 
achievement. The study found some negative impacts when leadership was used as a predictor of student achievement, specifically among students in the city of Chicago. These findings raise questions, not only about our understandings of direct and indirect roles that school leaders play in the development of collective efficacy levels and student achievement, but also the efficacy of the instrument itself (5Essentials Survey) and the use of the five essentials as factors critical to learning environment.

The study found moderate to high correlations between school leadership and the other efficacy factors with the least correlation found between Effective Leaders and Ambitious Instruction and the highest between Effective Leaders and Collaborative Teachers. In terms of student achievement, the highest correlations with efficacy factors were found between College Readiness and Involved Families followed by Supportive Environment. It seems, from this study that while school leadership has higher effects on teacher collaboration; teacher collaboration has the least effects on College Readiness/student achievement. On the other hand, collective efficacy factors of Involved Families and Supportive Environment predicted academic achievement (College Readiness), thus having the higher effects. In other words, a supportive environment in school and involved families seem to have greater impact on high school success compared to effective leader and teachers.

While these findings may point to the need for school leaders and their communities to focus on factors related to involving families and creating supportive environments (Calik et al., 2012); they also create the need to re-think the roles of school leaders and teachers in relation to high school student achievement. The questions that this study raises are: why did ambitious instruction not predict academic outcomes and why was ambitious instruction rated so highly by teachers and students? Donohoo, Hattie and Eells (2018) suggest that the role of the school leader is to "...help educators make the link between their collective actions and student outcomes" (p. 42). This research shows a gap between teacher actions and student achievement and suggests that teacher collective actions should focus on improving involvement of families and creating supportive environments in high schools. These may be done through identification and engagement with Bandura's efficacy informants that include mastery of performance accomplishments, vicarious experiences, verbal persuasions, and emotional arousals. As suggested by Bandura (1993), the practice of efficacy informants in the spirit of reciprocity can strengthen the relevant collective efficacy factors and their impacts on students' academic outcomes.

\section{Conclusions and Implications}

This study found that student achievement, as measured by college readiness, is most impacted by the involvement of families, followed by the supportive learning environments as perceived by teachers and students in response to the 5Essentials survey. This finding is supported by other research. For example, the development of peer and family networks, such as those discussed by Wolniak and 
Engberg (2009), Young, Johnson, Hawthorne and Pugh (2011), and Nelson and DeBacker (2008), show that positive experiences in high schools lead to secondary and post-secondary school success. Positive experiences, both personal and vicarious are the sources of positive connections to school and the development of a school-going culture, as described by Conley (2008). It is therefore, incumbent upon high schools to create greater opportunities for families to become engaged in the communal life of their high school. Specifically, school leaders should enable community involvement in the development and evaluation of school curricula, understanding of the school improvement planning process and knowledge of resources that can positively impact student academics, and exposure to educational experiences in which students and their families gain firsthand understanding and knowledge of the educational environment and how to navigate it. Just as Conley (2008) affirmed, the development of college knowledge leads to success in post-secondary schools and therefore, families should develop a deeper understanding of the high school system and build a sense of connectedness with opportunities for vicarious experiences, verbal persuasion, and emotional arousal for greater levels of collective efficacy and student achievement.

It is of the essence that schools take steps to create supportive environments that enable children to experience mastery in addition to the above-mentioned efficacy factors, specifically students that are in schools that serve large numbers of families of low-income. From the data presented in this study, along with research by Evans (2009) and Gordon, Klugman, Sebring and Sporte (2016), a strong relationship exists between low income status and low achievement scores. For this reason, ensuring that students see the learning environment as safe and welcoming is a critical first step to support learning. Making sure that interventions that relate to efficacy factors are in place so that when students experience academic and/or social challenges, actions that help them achieve some level of success and signals that perseverance is important, can be taken immediately.

It is essential that a clear, consistent message that defines rigorous instruction as it relates to student outcomes is provided for students and teachers in schools. In this study, even though Chicago high schools posted the lowest percentage of students meeting college readiness benchmarks, they reported the highest incidence of perceived levels of Ambitious Instruction. The perceived levels of ambitious instruction did not yield expected or predict academic outcomes. Considering that research that is the foundation for the 5Essentials Survey was done in Chicago schools (Gordon et al., 2016; Bryk et al., 2010), the hypothesis that the presence or practice of 5Essentials should have positive impacts on academic outcomes should have been especially true in Chicago schools. However, schools in Chicago reported high scores in collective efficacy factors, specifically Ambitious Instruction, but this did not correlate positively with or predict College Readiness as would be expected. Involved Families was the common predictor of student achievement in all groups with Supportive Environment being a predictor among rural and suburban high schools. This finding points to the unique challenges present in urban and low-income environments including extreme poverty, lowered expectations, lack of resources 
to create supportive environments for students, and perpetual lower academic achievement (Gehrke, 2005). The grip of these challenges seems too strong that even high levels of Ambitious Instruction cannot mitigate their effects. These challenges likely distort conceptualization of academic rigor to the extent that what students perceive as rigor does not yield high academic outcomes. Chicago schools had the lowest percentage of students that are college ready and the largest standard deviation, indicating the existence of extremes (absolute poverty and wealth) and the intensity of impacts. We recommend further investigation into the mismatch between student perceptions of academic rigor and academic achievement and to contextualize the usefulness of the 5Essentials in advancing learning in high schools and the use of the 5Essential Survey to determine school needs or school culture.

Based on the conceptual framework used in this study and our findings, we suggest a revised conception of the functions of the 5Essentials. First, we see Effective Leaders not just as inputs, but as major and active part of all aspects of throughput in the organization. The leaders serve as guides creating the parameters within which Collaborative Teachers interact and deliver Ambitious Instruction. Secondly, around the leader, teachers, and students is a Supportive Environment that cultivates safety, high expectations, and care for one another within the school. And thirdly, the supportive environment is enriched by strong relations with families and communities (Involved Families) who regularly access the school to support the school and the students.

\section{References}

ACT. (2004). On course for success: A close look at selected high school courses that prepare all students for college and work. Retrieved July 5, 2012, from https://bit. ly/37xzvcG.

Bandura, A. (1977). Self-efficacy: Toward a unifying theory of behavioral change. Psychological Review, 84(2), 191-215. Retrieved December 30, 2015, from https://bit.ly/30WinLm.

Bandura, A. (1993). Perceived self-efficacy in cognitive development and function. Educational Psychologist, 28(2), 117-148. Retrieved December 30, 2015, from https://bit.ly/2Gvnb0E.

Bandura, A. (2001). Social cognitive theory: An agentic perspective. Annual Review of Psychology, 52, 1-26. Retrieved on October 10, 2014 from https://bit.ly/2tTQCqK

Bennett, W.J. (1988). American education: making it work. A report to the president and the American people. (DOE Publication No. ED 289 959). Washington, D.C.: U.S. Government Printing Office. Retrieved January 25, 2016, from https://bit.ly/2R TKV48.

Bryk, A.S., Sebring, P.B., Allensworth, E., Luppescu, S. \& Easton, J.Q. (2010). Organizing schools for improvement: lessons from Chicago. Chicago, IL: The University of Chicago Press.

Calik, T., Sezgin, F., Kavgaci, H., \& Kilinc, A.C. (2012). Examination of relationships between instructional leadership of school principals and self-efficacy of teachers and collective teacher efficacy. Educational Sciences: Theory \& Practice, 12(4), 24982504. Retrieved January 1, 2016, from https://bit.ly/2OiipZ5. 
Conley, D.T. (2008). Rethinking college readiness. New Directions for Higher Education, 144, 3-13.

Day, C., \& Gurr, D. (2014). Leading schools successfully. In Leading Schools Successfully: Stories from the Field, C. Day \& D. Gurr (eds), (pp.1-6). New York: Routledge.

Donohoo, J., Eells, R.J., \& Hattie, J. (2018). The power of collective efficacy. Educational Leadership, 75(6), 41-44.

Eells, R.J. (2011). Meta-Analysis of the relationship between collective teacher efficacy and student achievement. Dissertations. Paper 133. Retrieved December 30, 2015 from https://bit.ly/38HlnOh.

Engberg, M.E., \& Wolniak, G.C. (2009). Examining the effects of high school contexts on postsecondary enrollment. Research in Higher Education, 51, 132-153. Retrieved November 13, 2016, from https://bit.ly/3184euR.

Evans, A. (2009). No Child Left Behind and the quest for educational equity: The role of teachers' collective sense of efficacy. Leadership and Policy in Schools, 8, 64-91.

Gehrke, R.S. (2005). Poor schools, poor students, successful teachers. Kappa Delta Pi Record, 42(1), 14-17. Retrieved November 11, 2016, from https://bit.ly/2tTnGz5.

Goddard, R.D., Hoy, W.K., \& Woolfolk-Hoy, A. (2000). Collective teacher efficacy: Its meaning, measure and impact on student achievement. American Educational Research Journal, 37(2), 479-508.

Goddard, R.D., Hoy, W.K., \& Woolfolk-Hoy, A. (2004). Collective efficacy beliefs: theoretical developments, empirical evidence, and future directions. Educational Researcher, 33(3), 3-13. Retrieved December 30, 2015 from https://bit.ly/2TZGTtG

Gordon, M., Klugman, J., Sebring, P.B., \& Sporte, S. (2016). Expanding the 5Es from Chicago to Illinois: How the 5E's relationship to student outcomes varies by content. Society for Research on Educational Effectiveness. Spring Conference Abstract template retrieved on November 01, 2016 from https://bit.ly/37yRiAu.

Hoy, W.K., Sweetland, S.R., \& Smith, P.A. (2002). Toward an organizational model of achievement in high schools: The significance of collective efficacy. Educational Administration Quarterly, 38(1), 77-93. Retrieved November 21, 2015, from https://bit.ly/2vlp5yG.

ILCS. §§105-5/10-17a (n.d.) Retrieved December 28, 2015 from https://bit.ly/36v5XLK.

Ingersoll, R. M., Sirinides, P., \& Dougherty, P. (2018). Leadership matters: Teachers' roles in school decision making and school performance. American Educator, 42(1), 13-18.

Katz, D. \& Kahn, R.L. (1978). The social psychology of organizations, 2 ed. New York: John Wiley \& Sons.

Klugman, J., Gordon, M.F., Sebring, P.B. \& Sporte, S.E. (2015). A first look at the 5Essentials in Illinois schools. Chicago, IL: UChicago, Consortium on Chicago School Research. Retrieved January 30, 2017 from https://bit.ly/36tFyxT.

Kober, N. (2007). Why we still need public schools: Public education for the common good. Washington, D.C.: Center on Education Policy. Retrieved on March 29, 2016 from https://bit.ly/2RwSZsr.

Leithwood, K., \& Jantzi, D. (1999). The relative effects of principal and teacher sources of leadership on student engagement with school. Education Administration Quarterly, 35(5), 679-706.

Nelson, R.M., \& DeBacker, T. K. (2008). Achievement motivation in adolescents: The role of peer climate and best friends. The Journal of Experimental Education, 76(2), 170-189. Retrieved June 10, 2012, from https://bit.ly/2uCpRqU.

No Child Left Behind Act of 2001, 20 U.S.C. $\$ 6319$ (NCLB) (2015). Retrieved February 6, 2016, from https://bit.ly/2RzGcWh. 
Ross, J.A. \& Gray, P. (2006). School leadership and student achievement: The mediating effects of teacher beliefs. Canadian Journal of Education, 29(3), 798-822. Retrieved on December 30, 2015 from https://bit.ly/2tZPNg7.

Rotter, J.B. (1966). Generalized expectancies for internal versus external control of reinforcement. Psychological Monographs: General and Applied, 80(1), Whole No. 609). Retrieved August 23, 2015, from https://bit.ly/2O2T9FK

UChicago Impact. (2015). Illinois 5Essentials FAQs. Retrieved December 28, 2015 from https://bit.ly/2vuv8Bh.

Willis, P. (1977). Learning to labor: How working class kids get working class jobs. New York: Columbia University Press.

Wolniak, G.C., \& Engberg, M.E. (2010). Academic achievement in the first year of college: Evidence of the pervasive effects of the high school context. Research in Higher Education, 51, 451-467. Retrieved on June 10, 2012, from_https://bit.ly/ 2Rx7pZB

Young, A., Johnson, G., Hawthorne, M., \& Pugh, J. (2011). Cultural predictors of academic motivation and achievement: A self-deterministic approach. College Student Journal, 45(1), 151-163. Retrieved on June 10, 2012, from_https://bit.ly/2O $7 \mathrm{~d} 2 \mathrm{vv}$. 